\title{
David Oliver: Is Matt Hancock really prioritising prevention over cure?
}

\author{
David Oliver consultant in geriatrics and acute general medicine
}

Berkshire

Last week Matt Hancock, health and social care secretary for England, gave a speech launching a new government document, Prevention is Better than Cure: Our Vision to Help You Live Well for Longer. ${ }^{12}$ After much advance publicity I was curious to see its contents. I'm enthused by the focus and I don't doubt his sincerity but, without cogent detail of meaningful investment, policy levers, and implementation plans, visions don't come true.

There's a framing preamble, the restatement of established expert consensus on prevention and public health, and key facts and figures. There's a series of ambitions. But the paper offers little tangible new policy, funding, or even a hint at workforce planning to deliver them.

It has a low cost focus on nudging, enabling, and supporting people to take personal responsibility for their health and lifestyle risks, which ignores the evidence about the effects of wider environmental factors or multiple indices of deprivation on individual choice. ${ }^{34}$ Crucially, it says nothing about increasing funding for public health or local authorities-or about tackling low pay, welfare, or benefits systems to reduce the socioeconomic disparities that beget health inequalities. ${ }^{5}$

Hancock described an aspiration to "prioritise investment in primary and community healthcare," but the paper lacks detail on how to do this, how much, and how quickly. It mentions developing a new alcohol strategy with no hint at a publication date, it ducks the issue of minimum unit pricing, ${ }^{6}$ and it says little on the serious under-provision of cessation services for smoking, drugs, and alcohol or any meaningful regulation of the food and drinks industry.

It discusses shifting more resources into primary and community care but doesn't mention the serious workforce gaps ${ }^{7-9}$ any timetable or mechanisms to achieve this, or the fact that the hospital sector is itself struggling seriously with capacity and demand.

Numerous government papers and strategies in this field have proved to be false dawns
The one truly visionary flourish is some speculation about the untapped potential of genomics, precision medicine, and predictive algorithms to target prevention. But this is very much a work in progress, whose costs and benefits are yet to be realised. ${ }^{10}$

The paper mainly groups together a range of existing national policy programmes whose impact is currently uncertain. But it fails to deal with serious structural and funding shortfalls or radical solutions, and it shifts responsibility from local or national government onto individuals and employers.

Of course, not all prevention lies in formal public health services, but public health budgets have been serially cut since $2010,{ }^{112}$ and the Health Foundation's analysis of the budget estimated further cuts of $£ 1 \mathrm{bn}$, as any additional funds for the NHS go into service provision and capital expenditure. ${ }^{13}$ If we expect wider communities, local government, and voluntary services to be key agents of change in the shift towards prevention - well, their budgets have been similarly cut, in turn affecting social care and support for people to remain healthy and independent. We'll have an idea, after the next spending review and the long awaited social care green paper, whether any of this will be reversed. ${ }^{14}$

I commend the health secretary for highlighting the importance of prevention. But we've had numerous government papers and strategies in this field before that have proved to be false dawns. Without being adequately resourced and backed by evidence based policy levers with teeth, there'll be another one in five years-and another $B M J$ columnist describing its limitations.

Competing interests: See www.bmj.com/about-bmj/freelance-contributors/davidoliver

Provenance and peer review: Commissioned; not externally peer reviewed.

1 Department of Health and Social Care. Prevention is better than cure-Matt Hancock's speech to IANPHI. 5 Nov 2018. https://www.gov.uk/government/speeches/prevention-isbetter-than-cure-matt-hancocks-speech-to-ianphi.

2 Department of Health and Social Care. Prevention is better than cure: our vision to help you live well for longer. 5 Nov 2018. https://www.gov.uk/government/publications/ prevention-is-better-than-cure-our-vision-to-help-you-live-well-for-longer. 
3 Office for National Statistics. An overview of lifestyles and wider characteristics linked to healthy life expectancy in England: June 2017. 28 June 2017. https://www.ons.gov.uk/ peoplepopulationandcommunity/healthandsocialcare/healthinequalities/articles/ healthrelatedlifestylesandwidercharacteristicsofpeoplelivinginareaswiththehighestorlowesthealthylife/ june2017.

4 Institute of Medicine (US) Committee on Assessing Interactions Among Social, Behavioral, and Genetic Factors in Health; Hernandez LM, Blazer DG, eds. Genes, behavior, and the social environment: moving beyond the nature/nurture debate. National Academies Press (US), 2006. https://www.ncbi.nlm.nih.gov/books/NBK19924/

5 Health Foundation. Health equity in England: the Marmot review 10 years on. 8 Oct 2018 https://bit.ly/2qB5qp5.

6 Oliver D. David Oliver: Government's approach to alcohol harm is incoherent. BMJ 2018;362:k3836. 10.1136/bmj.k3836 30206113

7 King's Fund. Our work on NHS care delivered in a community setting. https://www. kingsfund.org.uk/topics/community-services.

8 Imison C. Can we solve the nursing workforce crisis? Nuffield Trust. 21 Nov 2016. https: //www.nuffieldtrust.org.uk/news-item/can-we-solve-the-nursing-workforce-crisis.

9 Institute for Government. Performance tracker 2018: general practice. 2018. https://www. instituteforgovernment org.uk/publication/performance-tracker-2018/general-practice.
10 Health Innovation Network. NHS England TECS evidence base review-findings and recommendations. 28 April 2017. https://healthinnovationnetwork.com/wp-content/uploads/ 2017/08/NHS-TECS-Evidence-Base-Review-Findings-and-recommendations.pdf.

11 Buck D. Chickens coming home to roost: local government public health budgets for 2017/18. King's Fund. 12 July 2017. https://www.kingsfund.org.uk/blog/2017/07/localgovernment-public-health-budgets-2017-18.

12 Gainsbury S. NHS funding boost: the need to manage expectations. Nuffield Trust. 26 Oct 2018. https://www.nuffieldtrust.org.uk/news-item/nhs-funding-boost-the-need-tomanage-expectations.

13 Health Foundation. Response to the autumn budget 2018. 30 Oct 2018. https://www. health.org.uk/news/response-autumn-budget-2018.

14 Buck D. Prevention is better than cure-and actions speak louder ... King's Fund. 5 Nov 2018. https://www.kingsfund.org.uk/blog/2018/11/prevention-better-than-cure.

Published by the BMJ Publishing Group Limited. For permission to use (where not already granted under a licence) please go to http://group.bmj.com/group/rights-licensing/ permissions 